\title{
Delineation of precursors in murine spleen that develop in contact with splenic endothelium to give novel dendritic-like cells
}

\author{
Jonathan K. H. Tan, ${ }^{1}$ Pravin Periasamy, ${ }^{1}$ and Helen C. O'Neill ${ }^{1}$ \\ ${ }^{1}$ Research School of Biology, Australian National University, Canberra, Australia
}

\begin{abstract}
Hematopoietic cell lineages are best described in terms of distinct progenitors with limited differentiative capacity. To distinguish cell lineages, it is necessary to define progenitors and induce their differentiation in vitro. We previously reported in vitro development of immature dendritic-like cells (DCs) in long-term cultures (LTCs) of murine spleen, and in cocultures of spleen or bone marrow (BM) over splenic endothelial cell lines derived from LTCs. Cells produced are phenotypi-
\end{abstract}

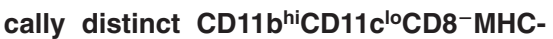
$\mathrm{II}^{-}$cells, tentatively named L-DCs. Here we delineate L-DC progenitors as different from known DC progenitors in BM and DC precursors in spleen. The progenitor is contained within the lineage-negative (Lin) ${ }^{-}$c-kit $^{+}$subset in neonatal and adult spleen. This subset has multipotential reconstituting ability in mice. In neonatal spleen, the progenitor is further enriched within the c-kitlo and $\mathrm{CD}^{\mathrm{l}} 4^{+}$subsets of Lin $^{-}$c-kit ${ }^{+}$cells. These cells seed cocul- tures of splenic endothelial cells, differentiating to give L-DCs that can activate T cells. L-DC progenitors are distinguishable from described splenic CD11c ${ }^{10}$ DC precursors and from Fms-like tyrosine kinase $3^{+}$DC progenitors in BM. Overall, this study confirms that LTCs are a physiologically relevant culture system for in vitro development of a novel DC type from spleen progenitors. (Blood. 2010; 115(18):3678-3685)

\section{Introduction}

Dendritic cells (DCs) are specialized antigen-presenting cells, which capture and process peripheral antigens for presentation to naive T cells. ${ }^{1}$ They exist in peripheral tissues as immature cells, displaying characteristics optimal for antigen uptake and surveillance of local environments. Under these conditions, they present apoptotic self cells to T cells to maintain peripheral tolerance. ${ }^{2,3} \mathrm{On}$ exposure to pathogens, DCs can also become immunogenic, adopting a mature, activated phenotype, a state distinct by additional secretion of proinflammatory cytokines, such as interleukin12, which promote effector T-cell differentiation. ${ }^{4}$

Multiple DC subsets are present in tissues around the body, and in spleen the main subsets include conventional DCs (cDCs) and plasmacytoid DCs (pDCs). cDCs are represented by 2 main populations of $\mathrm{CD} 8 \alpha^{-}$and $\mathrm{CD} 8 \alpha^{+} \mathrm{cDC}$. Morphologically, cDCs are small, nongranular cells ${ }^{5}$ that express high levels of CD11c and major histocompatibility complex class II (MHC-II) markers. ${ }^{6}$ pDCs are a distinct subset characterized by a small and plasmacytoid morphology, and a pronounced capacity to secrete high levels of IFN- $\alpha$ on viral stimulation. ${ }^{7,8}$

Isolating rare DC subsets for experimentation is a difficult task, and the isolation and study of DC precursors represent an even more challenging area. It is, however, necessary to delineate precursors to perform lineage experiments to define their downstream progeny. Indeed, examination of DC precursors from early granulocyte-macrophage colony-stimulating factor/interleukin- 4 cytokine culture systems has not been possible because of the enforced maturation of precursors. ${ }^{9,10}$ Recently, improved cultures of bone marrow (BM) cells with Fms-like tyrosine kinase 3 ligand (Flt3-L) have facilitated the study of DC development, ${ }^{11,12}$ with in vitro identification of 2 sequential cDC precursors $\mathrm{CD} 11 \mathrm{c}^{\text {int }} \mathrm{CD} 115^{+} \mathrm{c}^{-\mathrm{kit}^{-}}$pre-DCs and $\mathrm{CD} 11 \mathrm{c}^{-} \mathrm{CD} 115^{+}$c-kit ${ }^{\text {int }}$ pro-
DCs. ${ }^{13}$ Furthermore, in vivo counterparts of pre-DCs have been identified in spleen as CD $11 c^{\text {int } C D 43} 3^{\text {int }}$ SIRP- $\alpha{ }^{\text {int }}$ cells,,${ }^{14}$ and counterparts to pro-DC have been identified as $\mathrm{Lin}^{-} \mathrm{c}-\mathrm{kit}{ }^{\mathrm{lo}} \mathrm{Flt} 3^{+}$cells, present in BM but not spleen. ${ }^{15}$ Success in these studies highlights the value of in vitro culture systems for investigating DC development from precursors.

Previously, development of dendritic-like cells in spleen longterm cultures (LTCs) was demonstrated, which was unique in relation to other culture systems producing DCs. Cultures are continuous, maintaining 2 cell populations distinct in size as "small" and "large" cells. ${ }^{16}$ Large cells were previously characterized as a homogeneous population of immature myeloid dendriticlike $\mathrm{CD} 11 \mathrm{c}^{\mathrm{lo}} \mathrm{CD} 11 \mathrm{~b}^{\mathrm{hi}} \mathrm{CD} 8^{-} \mathrm{MHC}-\mathrm{II}^{-/ \mathrm{lo}}$ cells, named LTC-DCs. These were highly endocytic and weakly able to present antigen to CD4 ${ }^{+}$T cells. ${ }^{17,18}$ The identity of a precursor within the small cell population was resolved by sorting and coculturing small cells above a spleen stromal cell line, which supports LTC-DC development. ${ }^{16}$ This resulted in development of large, immature DCs. ${ }^{16,19}$ The stromal cells that support myelopoiesis have now been characterized as splenic endothelial cells. ${ }^{20-23}$ Cloned stromal cell lines support production of distinct dendritic-like cells from precursors contained within $\mathrm{BM}$ and spleen equivalent to those produced in LTCs. ${ }^{24,25}$ These have been tentatively named L-DCs. ${ }^{24}$

This paper characterizes precursors present in spleen that produce L-DCs in coculture over splenic endothelial stroma. Identification of these cells was based on previous evidence that the small cell population of LTCs contained cells expressing c-kit and Sca1. ${ }^{16,17}$ Here, we delineate the splenic precursor of L-DCs as a multipotential hematopoietic progenitor. This study identifies a potentially new pathway for myelopoiesis leading to DC production in spleen from endogenous progenitors.
Submitted June 22, 2009; accepted January 28, 2010. Prepublished online as Blood First Edition paper, March 4, 2010; DOI 10.1182/blood-2009-06-227108.

The publication costs of this article were defrayed in part by page charge payment. Therefore, and solely to indicate this fact, this article is hereby marked "advertisement" in accordance with 18 USC section 1734.

(C) 2010 by The American Society of Hematology 


\section{Methods}

\section{Animals}

C57BL/6J, C57BL/6.Tg(TcraTcrb)1100Mjb (OT-I), and C57BL/6.SJLPtprc $^{\text {aPep }}$ 3b/BoyJ (B6.SJL) mice were bred at the John Curtin School of Medical Research (Canberra, Australia) under specific pathogen-free conditions. Mice were housed and handled according to protocols approved by the Animal and Experimental Ethics Committee at the Australian National University (ANU, Canberra, Australia).

\section{Coculture assays for DC development}

Cells were cultured in Dulbecco Modified Eagle Medium (DMEM) supplemented as described previously (sDMEM) ${ }^{26}$ Cocultures involved overlay of dissociated spleen or BM cells, or purified subsets of spleen cells, on the STX3 spleen stromal line. STX3 was derived from an LTC established from B10.A(2R) mice, which ceased production of DCs over time with passage. ${ }^{27}$ STX3 is passaged at $80 \%$ to $90 \%$ confluence by scraping a section of stroma, pipetting repetitively to disaggregate cells, and then transferring cells into fresh medium. When allogeneic or syngeneic spleen or BM cells were cocultured over STX3, only myeloid dendritic-like cells were produced. ${ }^{24,25}$ To establish cocultures, STX3 stroma was grown to $80 \%$ to $90 \%$ confluence before addition of overlay cells at 1 to $5 \times 10^{5}$ cells $/ \mathrm{mL}$. For coculture maintenance, half medium was exchanged every 3 to 4 days. Cocultures became established by 7 to 10 days and were monitored in culture for cell production by photomicroscopy under phase or bright-field using a DMIRE2 inverted microscope (Leica) equipped with a $40 \times$ objective and a DFC digital camera (Leica). Images were processed using IM4.0 software (Leica) and prepared for publication using Photoshop CS3 (Adobe Systems Inc). When nonadherent cells were evident, cells were collected for marker analysis by flow cytometry or for functional assays.

\section{Analysis of cell-surface marker expression}

Antibody staining and flow cytometry were performed to distinguish cell subsets based on marker expression. To inhibit nonspecific antibody binding via Fc receptors, cells $\left(\sim 10^{6}\right)$ were incubated with anti-CD16/32 (FcR block; eBioscience) for 15 minutes on ice in a final volume of $25 \mu \mathrm{L}$ of FACS buffer (DMEM/1\% fetal calf serum/0.1\% $\mathrm{NaN}_{3}$ ). Cells were washed, and specific antibody (or isotype control) was absorbed to cells for 20 minutes on ice. Biotin- or fluorochrome-conjugated antibodies were specific for CD11c (N418; allophycocyanin), c-kit (2B8; phycoerythrin $[\mathrm{PE}]$ or fluorescein isothiocyanate $[\mathrm{FITC}]$ ), CD11b (M1/70; PE-Cy7 or FITC), CD45.1 (A20; FITC), CD34 (RAM34; FITC), Flt3 (A2F10; PE), and VCAM (429; FITC; eBioscience). Antibodies specific for Sca1 (E13-161.7; biotin), CD69 (H1-2F3; biotin), CD8 (53-6.7; PE), and MHC-II (25-9-17; biotin) were purchased from BD Biosciences. Isotype controls included hamster IgG (eBio299Arm), rat $\operatorname{IgG}_{2 \mathrm{a}}(\mathrm{eBR} 2 \mathrm{a})$, rat $\operatorname{IgG}_{2 \mathrm{~b}}$ (KLH/G2b-1-2), and mouse $\mathrm{IgG}_{2 \mathrm{a}}$ (eBM2a) from eBioscience, and rat IgG2a (R35-95) and hamster IgG1 (G235-2356) from BD Biosciences. After absorption of antibody, cells were washed twice. For addition of second-stage streptavidin-allophycocyanin-Cy7 (eBioscience), the same process was repeated. For analysis, cells were resuspended at $10^{7}$ cells $/ \mathrm{mL}$ in FACS buffer, and propidium iodide (PI: $1 \mu \mathrm{g} / \mathrm{mL}$; Sigma-Aldrich) added for discrimination of live and dead cells. Flow cytometry was performed immediately on a BD LSRII (BD Biosciences) and $3 \times 10^{4}$ to $1 \times 10^{6}$ events collected. BD FACSDiva Software (BD Biosciences) was used to acquire data. Data analysis involved postacquisition gating using FlowJo software (TreeStar).

To monitor proliferation of purified $\mathrm{T}$ cells after activation, cells were stained with 5- (and 6-) carboxyfluorescein diacetate succinimidyl ester (CFSE; Invitrogen). Proliferation was measured flow cytometrically by a decrease in fluorescence with cell division. For CFSE labeling, enriched preparations of T cells were washed and resuspended at less than $10^{7}$ cells/ $100 \mu \mathrm{L}$ in sDMEM. CFSE was added at a final concentration of $5 \mu \mathrm{M}$ and vortexed immediately to ensure uniform labeling. Cells were incubated at room temperature for 5 minutes with regular agitation before washing twice with sDMEM.

\section{Enrichment of myeloid precursors in spleen}

Red blood cells (RBCs) were removed from whole dissociated splenocytes of $\mathrm{C} 57 \mathrm{BL} / 6 \mathrm{~J}$ mice using lysis buffer $\left(0.14 \mathrm{NH}_{4} \mathrm{Cl}, 0.017 \mathrm{M}\right.$ Tris-base, $\mathrm{pH} 7.5$ ) treatment for 5 minutes at $20^{\circ} \mathrm{C}$. Cells were then washed twice, resuspended in FACS buffer $\left(10^{8}\right.$ cells $\left./ \mathrm{mL}\right)$, and filtered through a $70-\mu \mathrm{m}$ nylon cell strainer (BD Biosciences) before magnetic bead depletion of $\mathrm{T}$ and $\mathrm{B}$ cells and residual RBCs. For depletion, cells were labeled on ice for 15 minutes with biotinylated monoclonal antibodies specific for CD19 (clone: eBio1D3), Thy1.2 (30-H12), and TER-119, purchased from eBioscience. Cells were washed twice to remove unbound antibody and resuspended at $10^{8}$ cells $/ \mathrm{mL}$ in separation buffer (phosphate-buffered saline $/ 0.5 \%$ bovine serum albumin/2mM ethylenediaminetetraacetic acid/ $0.1 \% \mathrm{NaN}_{3}$ ). Cells were incubated with anti-biotin MACS microbeads (13- $\mu \mathrm{L}$ beads $/ 10^{8}$ cells; Miltenyi Biotec) for 20 minutes on ice, washed, and resuspended in separation buffer $\left(500 \mu \mathrm{L} / 10^{8}\right.$ cells). Cell depletion involved LS columns (Miltenyi Biotec) in a SuperMACS II Separation Unit (Miltenyi Biotec), washing 3 times with separation buffer and collecting unbound cells as flow-through.

\section{Cell sorting}

Sorting was performed using a BD FACSAria (BD Biosciences). Cells were prepared for flow cytometry as previously described, and all incubation and washing steps were performed strictly at $4^{\circ} \mathrm{C}$ in $\mathrm{NaN}_{3}$-free FACS buffer. After a final wash, cells were passed through a $70-\mu \mathrm{m}$ nylon cell strainer (BD Biosciences) to ensure removal of cell clumps before sorting. Cells were sorted into SDMEM for later culturing.

\section{In vivo reconstitution assays}

The hematopoietic potential of cell subsets was tested after adoptive transfer into genetically distinct irradiated host mice. Donor spleen cell subsets $\left(2 \times 10^{4}\right)$ were prepared by sorting from B6.SJL mice $\left(\mathrm{CD} 45.1^{+}\right)$. Cells were intravenously injected via the tail vein of C57BL/6J (CD45.2 $\left.{ }^{+}\right)$ recipient mice 4 to 6 weeks of age that had been irradiated 3 hours previously with $4.5 \mathrm{~Gy}$ (sublethal) or $9.5 \mathrm{~Gy}$ (lethal) whole body irradiation using a cobalt ${ }^{60}$ source. Lethally irradiated mice were given $10^{5}$ syngeneic $\mathrm{BM}$ cells to ensure survival. Irradiated mice were maintained on antibiotic water (neomycin sulfate, $1.1 \mathrm{~g} / \mathrm{L}$, Sigma-Aldrich; and polymyxin B sulfate, $10^{6} \mathrm{U} / \mathrm{L}$, Sigma-Aldrich) for 4 weeks. After 10, 20, or 41 days or 25 weeks, mice were killed and progeny cells identified in spleen using flow cytometry.

\section{Positive selection of DCs from spleen}

To obtain freshly isolated DCs, splenocytes were labeled with CD11 $\mathrm{c}^{+}$ microbeads $\left(15 \mu \mathrm{L} / 10^{8}\right.$ cells; Miltenyi Biotec) in a total volume of $10^{8}$ cells $/ \mathrm{mL}$ of separation buffer for 15 minutes on ice followed by washing. To isolate CD $11 \mathrm{c}^{+} \mathrm{DCs}$, cells were resuspended in separation buffer (500 $\mu \mathrm{L} / 10^{8}$ cells), run through a SuperMACS II Separation Unit equipped with an MS column (Miltenyi Biotec), and washed 3 times with buffer $(500 \mu \mathrm{L})$. Flow-through cells were discarded before addition of $1 \mathrm{~mL}$ of separation buffer to the column. The $\mathrm{CD} 11 \mathrm{c}^{+}$cell fraction was collected under pressure.

\section{Assays for antigen-specific T-cell activation by DCs}

The antigen-presenting capacity of DCs was assessed using purified T cells from OT-I T cell receptor-transgenic (TCR-tg) mice (TCR-V $\alpha 2 \mathrm{~V} \beta 5.1$ ) specific for the $\mathrm{K}^{\mathrm{b}}$ restricted peptide $\mathrm{OVA}_{257-264^{28}}$ or OT-II TCR-tg CD4 ${ }^{+}$ $\mathrm{T}$ cells specific for $\mathrm{IA}^{\mathrm{b}}$ ovalbumin (OVA). $\mathrm{CD} 8^{+} \mathrm{T}$ cells from OT-I mice and $\mathrm{CD}^{+} \mathrm{T}$ cells from OT-II mice were isolated from mesenteric lymph nodes by depletion of $\mathrm{MHC}-\mathrm{II}^{+}$antigen-presenting cells, B cells, and macrophages. The antibody cocktail contained anti-IA ${ }^{\mathrm{b} / \mathrm{k}}$ (clone: TIB120), anti-B220 (RA3-6B2), anti-CD4 (GK1.5), or anti-CD8 (53-6.7) and anti-CD11b (M1/70) prepared as hybridoma culture supernatant. Cells were labeled on ice and washed twice with separation buffer. To remove antibody-labeled leukocytes, cells were incubated with sheep anti-rat Ig Dynabeads $\left(50 \mu \mathrm{L}\right.$ beads $/ 10^{7}$ cells; Dynal) at $4^{\circ} \mathrm{C}$ for 25 minutes with 


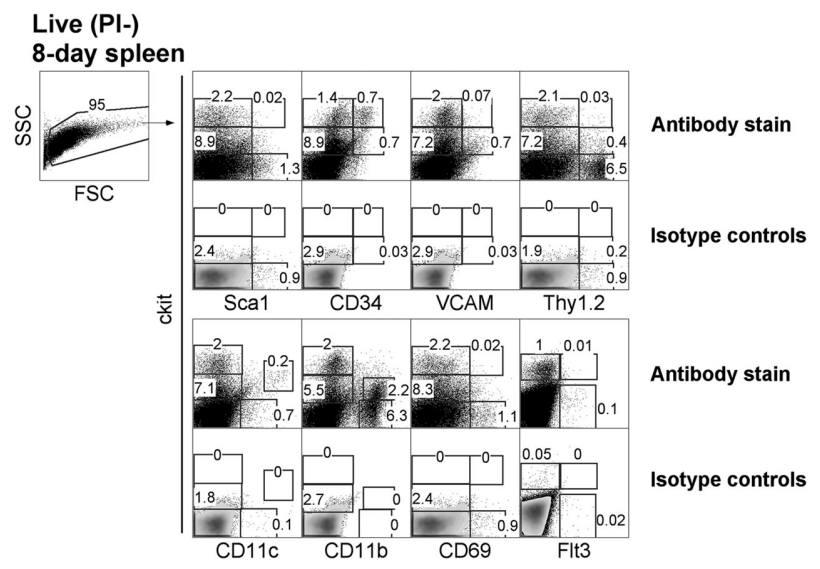

Figure 1. Characterization of DC precursors in neonatal spleen. C57BL/6J mice were analyzed for the presence of dendritic-like cells (DCs) and hematopoietic cell subsets by flow cytometric analysis for expression of c-kit, Sca1, CD34, VCAM, Thy1.2, CD69, Flt3, CD11c, and CD11b. Forward scatter (FSC) and side scatter (SSC) analysis was used to gate out debris, and isotype controls were used to determine background binding (shown as density plots) and to set gates. Specific antibody binding is shown by dot plots, and the percentage of cells is indicated in gates. Results are representative of 3 separate analyses.

rotation. For removal of $\mathrm{CD} 11 \mathrm{c}^{+} \mathrm{DCs}$, cells were also incubated with anti-CD11c microbeads ( $1.5-\mu \mathrm{L}$ beads $/ 10^{7}$ cells; Miltenyi Biotec). After placing cells in a magnetic particle concentrator (Dynal) for 2 minutes, supernatant containing unbound enriched $\mathrm{T}$ cells was transferred to a fresh tube for labeling with CFSE.

Antigen-presenting cells were pulsed with antigen (OVA) in vitro at $10^{7}$ cells $/ \mathrm{mL}$ in sDMEM for 12 hours using either 10 or $100 \mu \mathrm{g} / \mathrm{mL}$ OVA or hen egg lysozyme (HEL) as a control. To establish T-cell cocultures, enriched CFSE-labeled OT-I T cells were plated at $10^{4}$ to $10^{5}$ cells/well with diluting concentrations of antigen-presenting cells as stimulators in a total volume of $200 \mu \mathrm{L}$ of sDMEM. After 4 days, T-cell activation was assessed flow cytometrically to analyze cell division by reduction in CFSE intensity.

\section{Results}

\section{Characterization of L-DC precursors in spleen}

LTCs have been most successfully established from the spleens of neonatal 8-day-old mice. To investigate the presence of similar precursors in vivo, 8-day-old spleens were examined for cell subsets based on expression of c-kit, Sca1, CD34, and CD11c (Figure 1). In line with LTC precursors distinguishable by c-kit expression, 8-day spleen was found to segregate into clear c-kit ${ }^{-}$, $\mathrm{c}-\mathrm{kit}^{\mathrm{lo}}$, and c-kithi subsets. Furthermore, Sca1 was expressed on c-kithi cells representing $0.02 \%$ of total 8 -day-old spleen cells and on c-kit ${ }^{-}$cells $(1.3 \%)$ in accordance with populations identified among LTC small cells (all data not shown). Subsets of c-kit ${ }^{\text {hi }}$ splenocytes also coexpressed CD34 (0.7\%) and Thy 1.2 $(0.03 \%)$. CD34 was also expressed on a subset of c-kit ${ }^{\text {hi Sca }{ }^{+}}$ cells (data not shown). Subsets of spleen c-kit ${ }^{l o}$ cells coexpressed Thy $1.2(0.4 \%)$, CD34 (0.7\%), and VCAM-1 $(0.7 \%)$. Flt $3^{+}$cells were barely detectable among the c-kit ${ }^{+}$subset $(0.01 \%)$, consistent with an absence of progenitors for $\mathrm{cDCs}$ in spleen. ${ }^{29}$ All of these subsets are reflective of hematopoietic subsets described in BM. ${ }^{30}$

The expression of lineage markers CD11c and CD11b and the activation marker CD69 was also analyzed in relation to c-kit on cells. Cells expressing c-kit were $\mathrm{CD}^{-} 9^{-}$, consistent with their progenitor rather than activated or effector status. A clear c-kit ${ }^{\text {lo }} \mathrm{CD} 11 \mathrm{c}^{\text {hi }}$ DC population accounted for $0.2 \%$ of total spleen and was consistent with the presence of a small population of cDCs. ${ }^{11}$ A subset of $\mathrm{CD}_{11 \mathrm{~b}^{+}}$cells also expressed low levels of c-kit, reflecting myeloid precursors. Thus, 8-day-old neonatal spleen contains $\mathrm{c}-\mathrm{kit}^{\mathrm{lo}}$ and $\mathrm{c}-\mathrm{kit}^{\mathrm{hi}}$ populations, which can be investigated for their equivalence with precursors maintained in LTC-DCs.

Neonatal splenocytes were then sorted on the basis of c-kit expression and subsets cocultured over STX3 stroma to determine DC differentiative potential. Overlaid whole BM, known to produce DCs in coculture over STX3 stroma, ${ }^{21,24,25}$ was used as a positive control. Initially, spleen cells were depleted of $\mathrm{T}$ and $\mathrm{B}$ cells and then sorted on the basis of c-kit and CD11c expression, to yield c-kit ${ }^{-} \mathrm{CD} 11 \mathrm{c}^{-}$and c-kit ${ }^{+} \mathrm{CD} 11 \mathrm{c}^{-}$subsets for comparison (Figure 2A). After 14 days of coculture over STX3 stroma, progeny cells were collected and stained in a 4-color assay and analyzed by multichannel flow cytometry for markers that distinguish the main DCs and myeloid subtypes, that is, CD11c, CD11b, CD8 $\alpha$, and MHC-II. Both spleen c-kit ${ }^{+} \mathrm{CD} 11 \mathrm{c}^{-}$cells and whole BM yielded productive cocultures as assessed by phase microscopy (Figure 2B). Total cell production was monitored by forward scatter (FSC) analysis of progeny cells. Only control BM and sorted spleen c-kit ${ }^{+} \mathrm{CD} 11 \mathrm{c}^{-}$overlay cells produced progeny identifiable as events on FSC versus side scatter (SSC) plots (Figure 2C). Cells

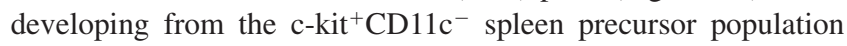
were heterogeneous and large in size. These were divisible into 2 populations of live $\left(\mathrm{PI}^{-}\right) \mathrm{CD} 11 \mathrm{c}^{+} \mathrm{CD} 11 \mathrm{~b}^{+} \mathrm{CD} 8 \alpha^{-} \mathrm{MHC}-\mathrm{II}^{-}$ LTC-DC-like cells (hereafter referred to as L-DCs) and $\mathrm{CD} 11 \mathrm{c}^{+} \mathrm{CD} 11 \mathrm{~b}^{+} \mathrm{CD} 8 \alpha^{-} \mathrm{MHC}^{-\mathrm{II}^{+}}$cells $\left(\mathrm{MHC}^{-\mathrm{II}^{+}} \mathrm{DCs}\right)$ more reflective of $\mathrm{CD} 8 \alpha^{-}$cDCs or monocyte-derived DCs. These populations made up $60 \%$ and $7.2 \%$ of live FSC $^{\text {hi }}$ cells, respectively. Exactly the same populations developed from cocultures estab-

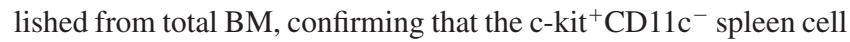
subset contains DC precursors.

To demonstrate that in vitro derived DCs were functionally competent antigen-presenting cells, cells were collected from cocultures, sorted to give a pure population, and then tested for ability to activate OT-I TCR-transgenic anti-OVA $\mathrm{CD}^{+} \mathrm{T}$ cells and OT-II TCR-transgenic anti-OVA CD4 ${ }^{+}$T cells. Cells were collected at 21 days, stained with CD11c, CD11b, and MHC-II and the L-DC population sorted as a CD11 $\mathrm{c}^{+} \mathrm{CD} 1 \mathrm{~b}^{+} \mathrm{MHC}^{-\mathrm{II}^{-}}$subset. The population of $\mathrm{CD} 11 \mathrm{c}^{+} \mathrm{CD} 11 \mathrm{~b}^{+} \mathrm{MHC}-\mathrm{II}^{+}$cells was too few for this assay. Freshly isolated splenic CD $11 c^{+}$DCs (f-DCs) were prepared as control antigen-presenting cells. This subset is highly enriched for $\mathrm{CD} 11 \mathrm{c}^{+} \mathrm{CD} 11 \mathrm{~b}^{+} \mathrm{MHC}^{-\mathrm{II}^{+}} \mathrm{cDCs}$ (data not shown). Coculture-derived cells were sorted to give L-DCs and pulsed with ovalbumin (OVA) or HEL as control antigen, with and without addition of lipopolysaccharide (LPS) as an activator. Antigenpulsed DCs were then tested for ability to activate purified CFSE-labeled CD8 ${ }^{+}$OT-I T cells or CD4 ${ }^{+}$OT-II T cells in a 4-day assay. Cell division measured by dilution of CFSE intensity showed that sorted coculture-derived L-DCs were capable of inducing OVA-specific CD8 ${ }^{+}$T-cell proliferation, which was not improved by LPS. A similar result was seen for control CD11 ${ }^{+}$ spleen DCs. Antigen-pulsed L-DCs were unable to activate OT-II $\mathrm{CD}^{+}{ }^{+} \mathrm{T}$ cells, consistent with an $\mathrm{MHC}-\mathrm{II}^{-}$phenotype. In contrast, fresh spleen $\mathrm{CD} 11 \mathrm{c}^{+}$cells gave a strong antigen-specific response in both the presence and absence of LPS. Cells developing in stromal cocultures from spleen precursors are functional antigenpresenting cells, although with restricted cross-priming capacity for only $\mathrm{CD}^{+} \mathrm{T}$ cells. These are established assays for antigen- 


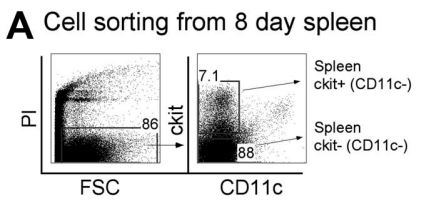

C DC production in co-cultures
B Cell production in co-cultures

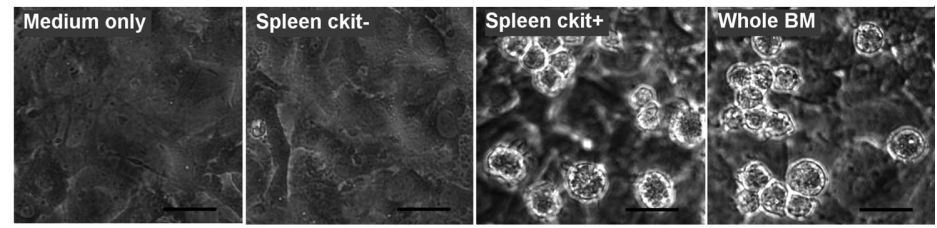

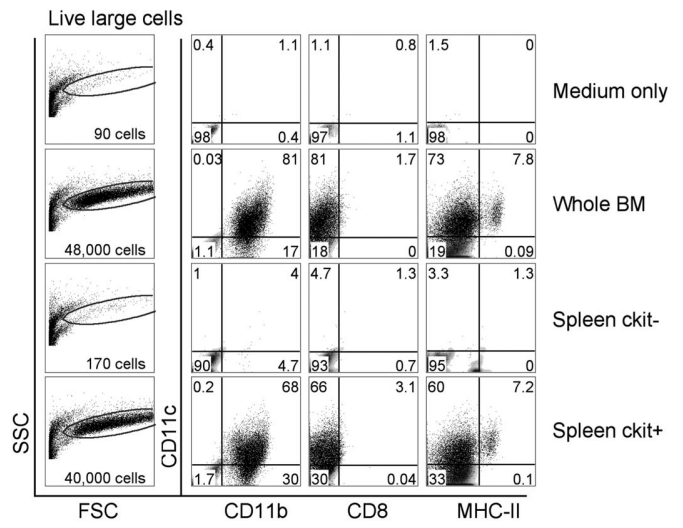
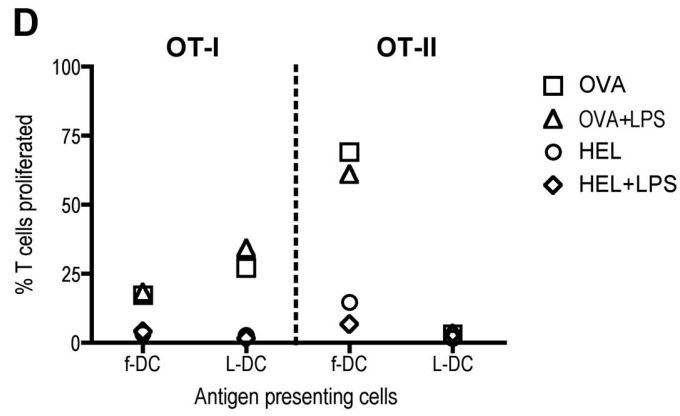

Figure 2. Identification of a DC precursor subset among neonatal spleen cells. (A) Eight-day-old spleen cells were sorted to give 2 populations of $\mathrm{C}^{-k i t^{+}} \mathrm{CD} 11 \mathrm{c}^{-}$and C-kit ${ }^{-}$CD11 ${ }^{-}$cells. (B) Equal numbers of cells were cocultured over STX3 to assess DC development, along with whole red blood cell (RBC)-lysed bone marrow (BM) as positive control, and STX3 stromal cells as negative control. Cocultures were observed under phase microscopy after 14 days. Bar represents $50 \mu \mathrm{m}$. (C) Total nonadherent progeny cells were collected from cocultures at 14 days and analyzed flow cytometrically. FSC and SSC parameters were used to distinguish large cells for analysis of relative cell yield and marker analysis. Cells were simultaneously stained for CD11c, CD11b, CD8 $\alpha$, and MHC-II to delineate DC subsets. Positive staining cells (dot plot) were gated using relevant isotype controls (density plot). Percentage of positive cells relative to all cells collected from cocultures is indicated in quadrants. (D) L-DCs produced in cocultures were tested for the capacity to activate purified CD8 ${ }^{+}$OT-I TCR-tg T cells or CD4 ${ }^{+}$OT-II TCR-tg T cells. L-DCs were collected from cocultures of CD11 ${ }^{-}$C-kit $^{+}$ spleen after 21 days. Control f-DCs were isolated from spleen using CD11c ${ }^{+}$MACS microbeads. Antigen-presenting cell subsets were pulsed with antigen (10 $\mu$ g/mL OVA for OT-I, or $100 \mu \mathrm{g} / \mathrm{mL}$ OVA for OT-II) in vitro for 12 hours before addition of CFSE-labeled T cells. Cocultures were established at a 1:5 DC:T-cell ratio, in the presence and absence of LPS $(10 \mu \mathrm{g} / \mathrm{mL})$, which was washed off after 12 hours. HEL was control antigen. T-cell activation was measured flow cytometrically after gating live $\left(\mathrm{PI}^{-}\right) \mathrm{CD} 11 \mathrm{c}^{-} \mathrm{CD} 8^{+} \mathrm{OT}-\mathrm{I} \mathrm{T}$ cells, or $\mathrm{PI}^{-} \mathrm{CD} 11 \mathrm{c}^{-} \mathrm{CD} 4^{+} \mathrm{OT}-\mathrm{II} \mathrm{T}$ cells). Data are presented as percentage of $\mathrm{T}$ cells proliferating on the basis of reduction in $\mathrm{CFSE}$ intensity. Data are representative of 2 similar experiments.

specific T-cell activation, and their use here was only limited by the small number of L-DCs produced in cocultures.

Neonatal splenocytes were next sorted into c-kit ${ }^{-},{\mathrm{c}-k i t^{\mathrm{lo}}}$, and c-kit ${ }^{\text {hi }}$ subsets (Figure 3A) and assayed for DC development in cocultures by multicolor flow cytometry. Cell production was analyzed between 13 and 30 days, and common cell populations across multiple plots indicated by either square or round gates. Cell production was only observed from spleen c-kit ${ }^{\text {lo }}$ and c-kit ${ }^{\text {hi }}$ precursors (Figure 3B-C), consistent with previous experiments. In productive cocultures, 2 cell populations were clearly identifiable as $\mathrm{CD} 11 \mathrm{c}^{\mathrm{lo}} \mathrm{CD} 11 \mathrm{~b}^{\mathrm{hi}} \mathrm{MHC}-\mathrm{II}^{-} \mathrm{L}-\mathrm{DC}$ and $\mathrm{CD} 11 \mathrm{c}^{+} \mathrm{CD} 11 \mathrm{~b}^{\mathrm{lo}} \mathrm{MHC}-$ $\mathrm{II}^{+} \mathrm{cDCs}$ (Figure 3C). These 2 populations were clearly distinguishable in cocultures established from both c-kit ${ }^{\text {lo }}$ and c-kit ${ }^{\text {hi }}$ spleen cells. $\mathrm{CD} 11 \mathrm{c}^{\mathrm{lo}} \mathrm{CD} 11 \mathrm{~b}{ }^{\mathrm{hi}}$ cells were negative for MHC-II (round
A Sorting 8 day spleen

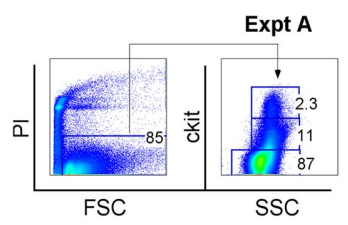

B Micrographs of 13 day co-cultures
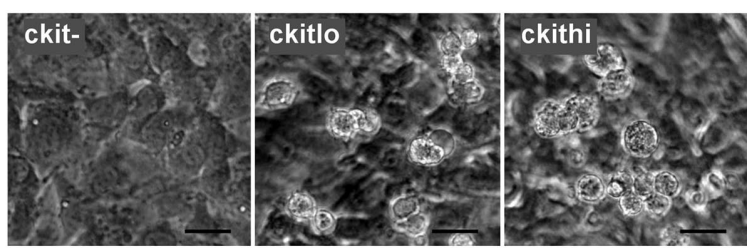

C Cell production in co-cultures
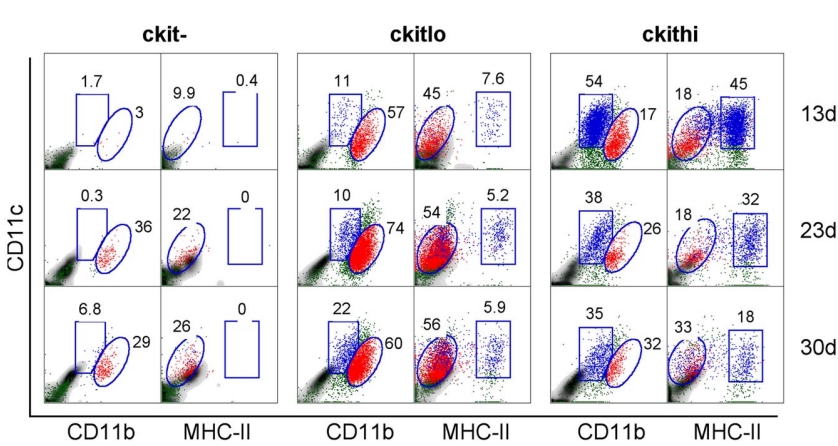

CD11b MHC-II

Figure 3. Further characterization of precursors in sorted into 3 populations of c-kit ${ }^{-}, c-k^{2} i^{+o}, c-k i t^{\text {hi }}$ cells (Expt A) and cocultured in equal number over STX3. (B) Cell production was monitored by photography under phase microscopy after 13 days. Bar represents $50 \mu \mathrm{m}$. (C) Nonadherent cells were collected from individual cocultures at 13,23 , and 30 days. Cells were simultaneously stained for CD11c, CD11b, CD8 $\alpha$, and MHC-II. FSC and SSC analysis was used to gate large cells for marker analysis to assess DC production. Isotype controls were used to determine background binding (density plots) and set gates. Square and round gates were used to identify common populations across different plots. Percentage of cells showing specific staining is indicated within gates. Staining for CD8 was negative (data not shown). Results are reflective of 2 similar experiments. 
A

Sorting 8 day spleen

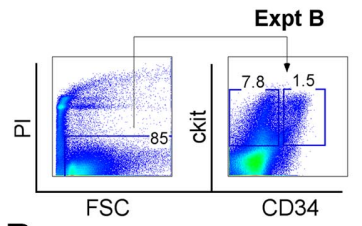

B

Cell production in co-cultures

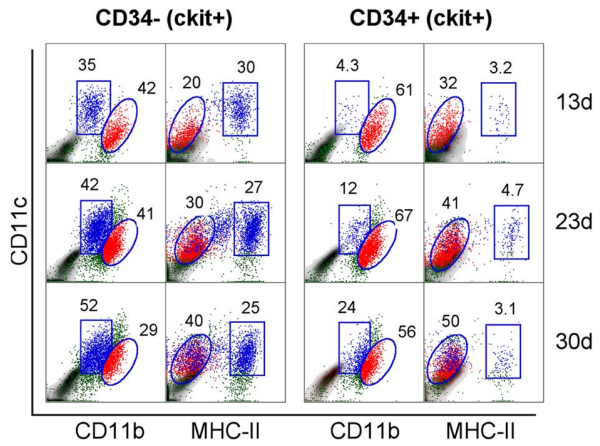

Figure 4. Progenitors are enriched within the $\mathrm{c}-\mathrm{kit}^{+} \mathrm{CD} 34^{+}$subset of neonatal

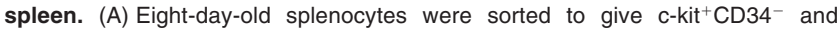

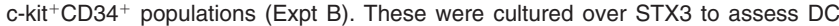
development. (B) Over time, nonadherent cells were collected from cocultures and assessed for DC production flow cytometrically. Cells were simultaneously stained for CD11c, CD11b, CD8 $\alpha$, and MHC-II. FSC and SSC analysis was used to gate large cells, and isotype controls were used to indicate background antibody binding (density plots) and set gates. Square and round gates identify common populations across different plots, and percentage of cells showing specific binding is indicated within gates. Staining for CD8 was negative (data not shown). Results are reflective of 2 similar experiments.

gates, red dots), and $\mathrm{CD} 11 \mathrm{c}^{\text {hi }} \mathrm{CD} 11 \mathrm{~b}^{\text {lo }}$ cells were positive for MHC-II expression (square gates, blue dots). Spleen c-kit ${ }^{\text {lo }}$ precursors produced predominantly L-DC progeny from as early as 13 days and out to 30 days $(45 \%-56 \%)$, with only a minor population of $\mathrm{CD} 8 \alpha^{-}$DCs $(7.6 \%-5.9 \%)$. Conversely, c-kit ${ }^{\text {hi }}$ precursors produced mainly MHC-II ${ }^{+}$DC $(45 \%)$ at 13 days, but this cell production was transient, with levels declining over 30 days to $18 \%$ of cells. In these cultures, the population of $\mathrm{CD} 11 \mathrm{c}^{\mathrm{lo}} \mathrm{CD} 11 \mathrm{~b}^{\text {hi }} \mathrm{MHC}-\mathrm{II}^{-}$cells appeared to predominate cultures only at the 30-day time point. Very low cell production observed from c-kit ${ }^{-}$precursors after 23 days could represent cell development from a few contaminating c-kit-expressing precursor cells that were not distinguishable by marker expression.

Neonatal spleen was found to contain a minor subset of c-kit ${ }^{+} \mathrm{CD} 34^{+}$cells (Figure 1). When spleen cells were sorted to give the $\mathrm{c}-\mathrm{kit}^{+}$subsets of $\mathrm{CD} 34^{-}$and $\mathrm{CD} 34^{+}$precursors, these populations showed differential ability to produce DCs in cocul-

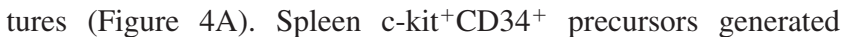
mainly CD $11 \mathrm{c}^{\text {lo }} \mathrm{CD} 11 \mathrm{~b}^{\text {hi }} \mathrm{MHC}-\mathrm{II}^{-}$L-DCs $(32 \%-50 \%)$ across 13 , 23 , and 30 days. In these cultures, $\mathrm{MHC}-\mathrm{II}^{+} \mathrm{DC}$ development was almost nil (3.1\%-4.7\%). In contrast, the c-kit ${ }^{+} \mathrm{CD} 34^{-}$spleen

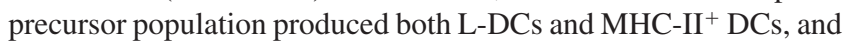
so may contain a subset of L-DC progenitors. Approximately equal numbers of L-DCs $(20 \%-40 \%)$ and $\mathrm{MHC}^{-\mathrm{II}^{+}}$DCs $(25 \%-30 \%)$ were evident across 13, 23, and 30 days (Figure 4B). This suggests that the c-kit ${ }^{+} \mathrm{CD} 34^{+}$subset contains the L-DC precursor and lacks a precursor of $\mathrm{MHC}^{-\mathrm{II}^{+}}$DCs present in the c-kit ${ }^{+} \mathrm{CD} 34^{-}$population. However, because a c-kit ${ }^{+} \mathrm{CD} 34^{+}$subset has not been found in adult spleen (all data not shown), it would appear that this is not the only L-DC progenitor phenotype.
The kinetics of cell development in cultures does not support a model whereby MHC-II ${ }^{-}$L-DCs are precursors of $\mathrm{MHC}^{-\mathrm{II}^{+}} \mathrm{DCs}$ (Figure 5). Over time, the number of $\mathrm{MHC}-\mathrm{II}^{+}$DCs produced decreases over 30-day cocultures, and this was not associated with a decrease in L-DC numbers. The evidence presented here supports L-DCs and $\mathrm{CD} 11 \mathrm{c}^{+} \mathrm{CD} 11 \mathrm{~b}^{\mathrm{lo}} \mathrm{MHC}-\mathrm{II}^{+}$DCs as separate cell types. Overall, 8-day-old spleen contains several precursor populations that display differential ability for production of these 2 cell types in vitro (Figure 5B). Precursors of L-DCs were found to be highly enriched among the c-kit ${ }^{\mathrm{lo}}$ subset of $\mathrm{Lin}^{-} \mathrm{c}-\mathrm{kit}^{+}$cells, and also among the $\mathrm{CD}_{3}{ }^{+}$subset present in neonatal spleen. This result is consistent with analysis of LTCs where preliminary evidence indicated that precursors were found to be present among both c-kit ${ }^{\mathrm{lo}} \mathrm{CD} 34^{-}$and $\mathrm{c}-\mathrm{kit}^{\mathrm{lo}} \mathrm{CD} 34^{+}$subsets (data not shown). However, for LTCs, phenotypic analysis of progeny was limited by the small numbers of cells produced.

Data obtained in coculture experiments using progenitor subsets isolated out of 8-day-old spleen are summarized in Figure 5. Overall, only c-kit ${ }^{+}$spleen cell subsets produced DCs (Figure 5A). The c-kit ${ }^{l o}$ precursor population was more highly enriched for precursors of L-DC, whereas the c-kithi population contained precursors of both L-DCs and $\mathrm{MHC}-\mathrm{II}^{+}$DCs. However, the latter were lost over time, suggesting that they derived from a precursor that was not self-renewing. In contrast, c-kit ${ }^{l o}$ cells produce progeny for up to 30 days. Among c-kit ${ }^{+}$cells, the $\mathrm{CD} 34^{+}$subset is more highly enriched for L-DC precursors than the CD34although both are good producers of L-DCs. CD34 does not therefore appear to be a definitive marker of the L-DC precursor.

\section{Identification of precursors of LTC-DC-like cells in adult spleen}

The hematopoietic environment in neonatal spleen is dynamic with transient increases in both stem cells and progenitors for up to several
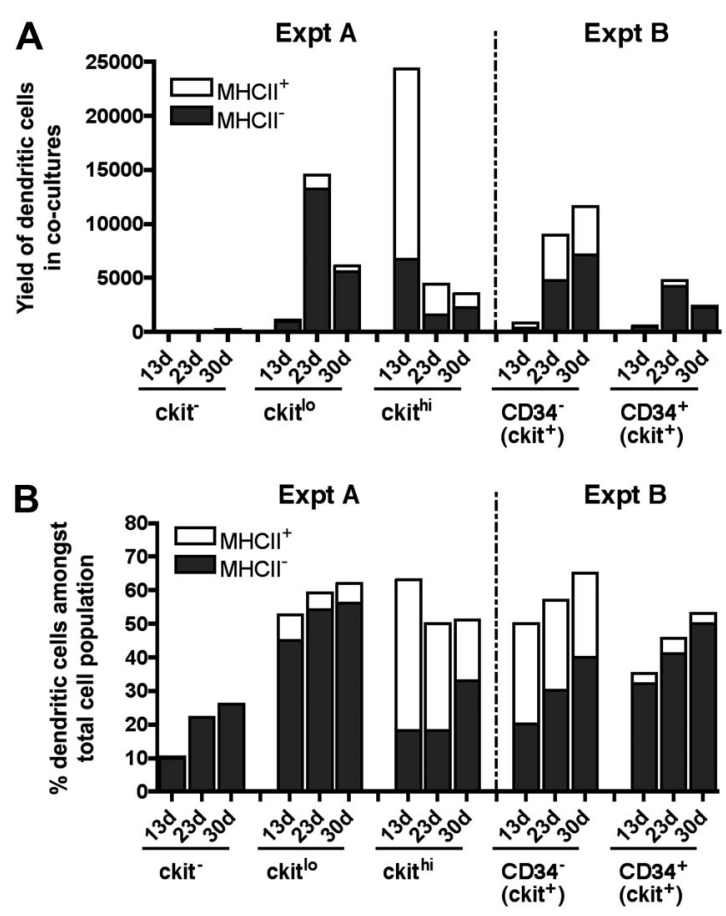

Figure 5. Subset analysis of cells produced in cocultures. Data from experiments performed in Figures 3 (Expt A) and 4 (Expt B) are summarized. DCs were identified among nonadherent progeny as CD11 $\mathrm{C}^{\text {lo }} \mathrm{CD} 11 \mathrm{~b}^{\text {hi }} \mathrm{MHC}-\mathrm{II}^{-}$(MHC-II- LTC-DC-like) or as $\mathrm{CD} 11 \mathrm{c}^{\text {hiCD}} \mathrm{C11} \mathrm{b}^{\text {lo }} \mathrm{MHC}-\mathrm{II}^{+}$(MHC-II+CD8 $\alpha^{-}$DC-like) cells. Cell production was compared at 13,23 , and 30 days in terms of cell yield or number of DCs produced $(A)$, and percentage of DCs among total cells produced in cocultures (B). 
A Adult spleen sorted populations

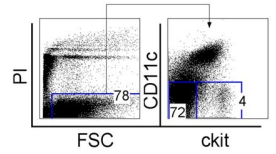

B Adult spleen sorted populations in STX3 co-culture
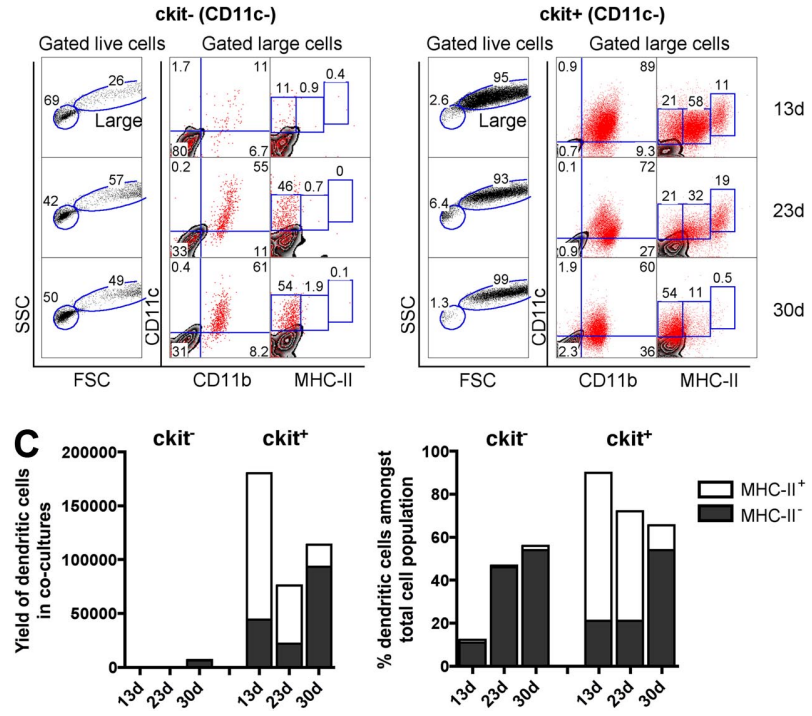

Figure 6. Adult spleen contains progenitors of LTC-DCs. (A) Adult splenocytes depleted of $T$ and $B$ cells were sorted into populations of $\mathrm{C}^{-k^{-}}{ }^{-} \mathrm{CD} 11 \mathrm{c}^{-}$and

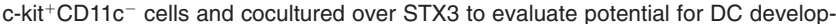
ment. (B) Nonadherent progeny cells collected from cocultures at 13, 23, and 30 days were assessed for DC production flow cytometrically. Cells were stained simultaneously for CD11c, CD11b, CD8 $\alpha$, and MHC-II. FSC and SSC parameters were used to distinguish large cells for multichannel marker analysis. Isotype controls were used to define background antibody binding (zebra plots) and set gates. The percentage of cells showing specific binding is indicated within gates. Staining for CD8 was negative (data not shown). (C) DC production from 13-, 23-, and 30-day cocultures established with adult c-kit ${ }^{-} \mathrm{CD} 11 \mathrm{c}^{-}$and c-kit ${ }^{+} \mathrm{CD} 11 \mathrm{c}^{-}$spleen cell subsets is summarized. Cells produced were identified as either $\mathrm{CD} 11 \mathrm{c}^{\mathrm{lo}} \mathrm{CD} 11 \mathrm{~b}^{\text {hi }} \mathrm{MHC}-\mathrm{II}^{-}$

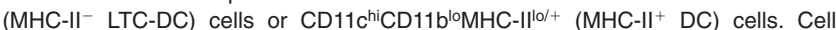
production is shown in terms of absolute number and yield of DCs, or percentage DCs among total cells produced in cocultures.

days after birth. ${ }^{31}$ To confirm that the presence of L-DC precursors in 8-day-old spleen was not a temporal phenomenon related to fluctuating progenitor levels, adult spleen was also investigated for the presence of L-DC precursors. Adult splenocytes depleted of $\mathrm{T}$ and $\mathrm{B}$ cells (CD19- Thy 1.2-) were stained and sorted to isolate the CD11 ${ }^{-} \mathrm{c}-\mathrm{kit}^{-}$ and $\mathrm{CD} 11 \mathrm{c}^{-} \mathrm{c}-\mathrm{kit}^{+}$cell populations (Figure 6A). These were cocultured over STX3 stroma for 30 days. Adult spleen CD11 $\mathrm{c}^{-} \mathrm{c}-\mathrm{kit}^{+}$precursors gave rise to large-sized cells ( $\mathrm{FSC}^{\text {hi }}>>93 \%$ ) over 30-day cultures (Figure 6B). In contrast, the majority of cells arising from CD11c ${ }^{-}$c-kit ${ }^{-}$ precursors were small cells (FSC ${ }^{\mathrm{lo}}$; 42\%-69\%), with very low yield of $\mathrm{CD}_{11 \mathrm{c}^{+}}$DCs. Cells recovered, however, had a $\mathrm{CD} 11 \mathrm{c}^{\mathrm{lo}} \mathrm{CD} 11 \mathrm{~b}^{\text {hi }} \mathrm{MHC}^{-} \mathrm{II}^{-}$phenotype reflecting L-DCs and could have arisen from contaminating c-kit ${ }^{\text {lo }}$ expressing cells not distinguishable by sorting.

The total yield of CD11 $\mathrm{c}^{+}$DCs from cocultures of adult spleen

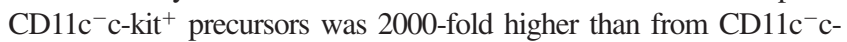
$\mathrm{kit}^{-}$precursors (Figure $6 \mathrm{C}$ ). Whereas large-sized cells produced in cocultures of spleen $\mathrm{CD} 11 \mathrm{c}^{-} \mathrm{c}-\mathrm{kit}^{+}$precursors uniformly expressed $\mathrm{CD} 11 \mathrm{c}$ and $\mathrm{CD} 11 \mathrm{~b}$, progeny were divisible into $\mathrm{MHC}^{-\mathrm{II}^{-}}$, MHC- $\mathrm{II}^{\mathrm{lo}}$, and MHC-II ${ }^{\text {hi }}$ subpopulations. However, MHC-IIlo and MHC-II ${ }^{\text {hi }}$ populations were only observed early in cultures at 13 and 23 days (Figure $6 \mathrm{~B})$, leaving predominantly $\mathrm{MHC}^{-\mathrm{II}^{-}} \mathrm{LTC}^{-D C}$-like cells after 30 days. MHC-II ${ }^{+}$DCs reduced in number by 4 -fold between 23 and 30 days in culture. In contrast, the percentage of $\mathrm{MHC}^{-\mathrm{II}^{-}} \mathrm{L}-\mathrm{DCs}$ increased 2.5-fold over this time. Thus, DC precursor activity was only evident among the $\mathrm{Lin}^{-} \mathrm{CD} 11 \mathrm{c}^{-} \mathrm{c}-\mathrm{kit}{ }^{+}$cell fraction of adult spleen, and these precursors gave rise to an increasing, stable population of CD $11 \mathrm{c}^{\text {lo }} \mathrm{CD} 11 \mathrm{~b}^{\text {hi }} \mathrm{MHC}-\mathrm{II}^{-}$L-DCs, but a transient population of

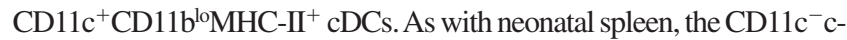
$\mathrm{kit}^{+}$spleen fraction appears to contain a small number of immediate precursors of $\mathrm{MHC}-\mathrm{II}^{+}$DCs along with a self-renewing progenitor of L-DCs.

The capacity of cocultures to support hematopoiesis could mean either that stromal cell lines are restricted in their hematopoietic support capacity or that $\mathrm{Lin}^{-} \mathrm{c}-\mathrm{kit}^{+}$precursors are restricted in their differentiative capacity to give only L-DCs. To distinguish these possibilities, the in vivo hematopoietic reconstitution capacity of progenitors was assessed. Adult splenocytes from B6.SJL (CD45.1) mice were depleted of $\mathrm{T}$ and B cells $\left(\mathrm{CD} 19^{-}\right.$Thy1.2- $2^{-}$, sorted into CD11c ${ }^{-} \mathrm{CD} 11 b^{-}\left(\mathrm{Lin}^{-}\right)$ populations of ${\mathrm{c}-\mathrm{kit}^{-}}^{-}$and c-kit ${ }^{+}$cells. In a first experiment, cells were adoptively transferred into sublethally irradiated C57BL/6J (CD45.2) mice and analyzed at 10,20, and 41 days for donor reconstitution (Figure 7A). C57BL/6J mice injected with Hanks balanced salt solution only were used as control donors (nil). This study tests the null hypothesis that complete absence of donor cell reconstitution means there are no progenitors among donor cells. A finding of just 1 animal containing donor progeny cells refutes that hypothesis. At 10 days, host mice showed no reconstitution (data not shown); whereas at 20 days, 1 of 4 sublethally irradiated mice given $\mathrm{Lin}^{-} \mathrm{c}-\mathrm{kit}^{-}$cells showed donorderived CD $45.1^{+}$cells. This result indicates a progenitor frequency of $0.0014 \%$ with a lower $95 \%$ confidence limit of $0.000064 \%$ using the Clopper-Pearson procedure. ${ }^{32}$ Three of 6 mice given $\mathrm{Lin}^{-} \mathrm{c}-\mathrm{kit}{ }^{+}$cells displayed donor-derived CD45.1 ${ }^{+}$cells, evident at 20 days in 1 mouse and at 41 days in 2 others. This represents a progenitor frequency of $0.0035 \%$ with a lower $95 \%$ confidence limit of $0.00083 \%$. Reconstitution was assessed by staining for lymphoid $\left(\mathrm{CD}^{+} \mathrm{CD} 11 \mathrm{c}^{-}\right)$, myeloid $\left(\mathrm{CD} 11 \mathrm{~b}^{\text {hi }} \mathrm{CD} 11 \mathrm{c}^{-}\right)$, and DC $\left(\mathrm{CD} 11 \mathrm{c}^{+} \mathrm{MHC}-\mathrm{II}^{+}\right)$subsets.

In a second experiment, donor mice were lethally irradiated and hosts analyzed after 25 weeks. Each of 4 mice given Lin $^{-}$c-kit ${ }^{+}$spleen cells showed robust donor cell reconstitution, whereas 1 mouse given donor $\mathrm{Lin}^{-} \mathrm{c}-\mathrm{kit}^{-}$did not. In this experiment, donor progeny were detected as DCs $\left(\mathrm{CD} 11 \mathrm{c}^{+}\right)$and myeloid cells $\left(\mathrm{CD} 11 \mathrm{~b}^{+} \mathrm{CD} 11 \mathrm{c}^{-}\right)$. Donor type $\mathrm{B}$ cells $\left(\mathrm{CD} 19^{+}\right)$and $\mathrm{T}$ cells $\left(\mathrm{CD}^{+}\right)$were also identified. Therefore, spleen $\mathrm{Lin}^{-} \mathrm{c}-\mathrm{kit}^{+}$progenitors demonstrated in vivo differentiative potential for multiple lymphoid, myeloid, and DC subsets.

Overall, the L-DC precursor is contained within the $\mathrm{Lin}^{-} \mathrm{c}-\mathrm{kit}^{+}$ population of spleen, which also contains multipotential progenitors. This study also identifies splenic stromal cocultures as capable of restricted long-term support for differentiation of only L-DCs, and no other DCs or hematopoietic cell type.

\section{Discussion}

In this study, we identify the presence of an L-DC precursor among a subset of multipotential progenitors present in spleen. This subset can be demonstrated in both neonatal (8-day) and adult spleen, although neonatal spleen yields higher numbers of these cells. The subset that produces L-DCs in STX3 stromal cocultures appears to be a in $^{-} \mathrm{CD} 11 \mathrm{c}^{-} \mathrm{c}-\mathrm{kit}^{+} \mathrm{CD} 34^{+/-} \mathrm{Flt} 3^{-}$population, present in both neonatal and adult spleen. In neonatal spleen, L-DC progenitors were present in both the $\mathrm{Lin}^{-} \mathrm{c}-\mathrm{kit}^{\mathrm{hi}}$ and the $\mathrm{Lin}^{-} \mathrm{c}-\mathrm{kit}^{\mathrm{lo}}$ subpopulations, although enriched in the latter. They were also present among the $\mathrm{CD}_{3} 4^{-}$and $\mathrm{CD}_{4} 4^{+}$subpopulations of $\mathrm{Lin}^{-} \mathrm{c}-\mathrm{kit}^{+}$cells, although they were greatly enriched among the $\mathrm{CD}^{+} 4^{+}$subsets. However, L-DC progenitors are present among the Lin $^{-} \mathrm{c}-\mathrm{kit}^{+}$ 

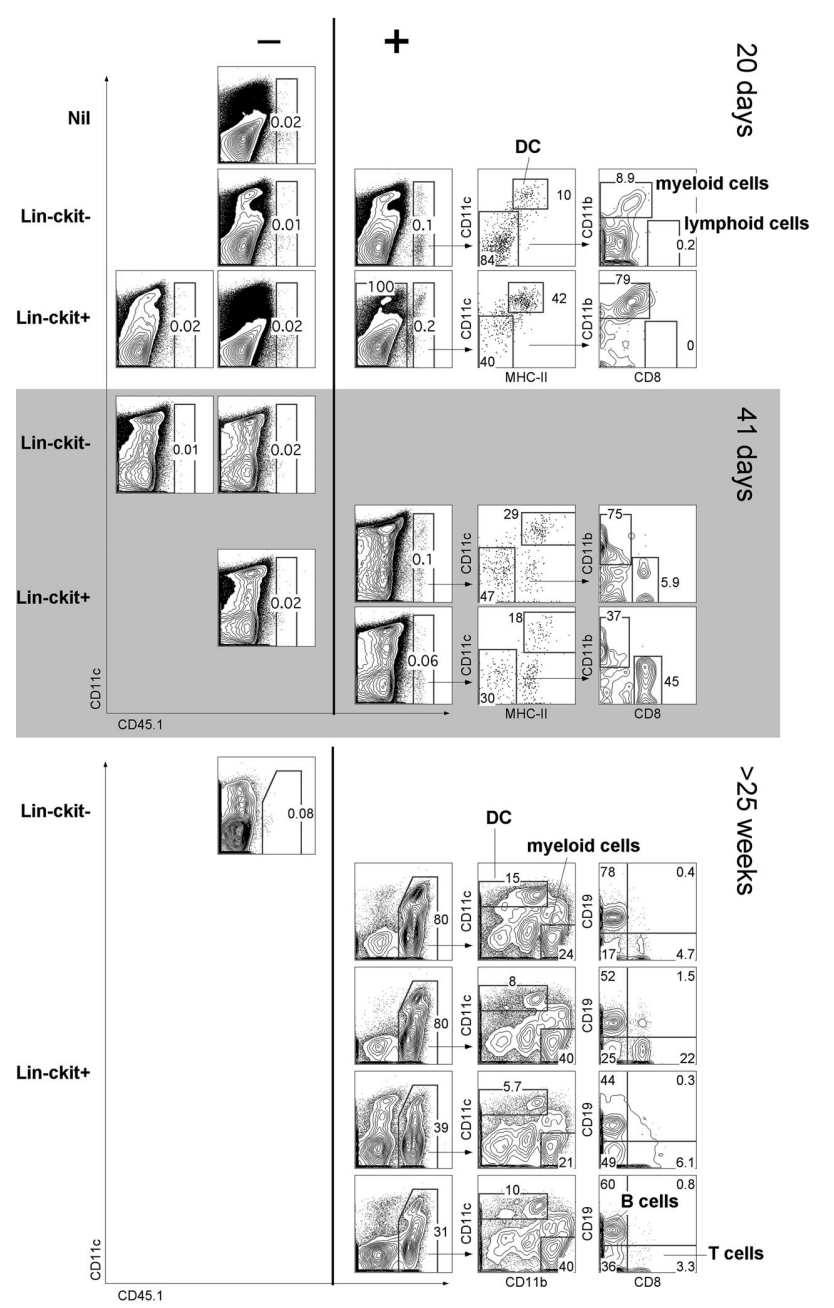

Figure 7. In vivo differentiative potential of spleen precursors. Splenocytes of adult B6.SJL mice were depleted of $\mathrm{T}$ and $\mathrm{B}$ cells and sorted to give $\mathrm{CD} 11 \mathrm{c}^{-} \mathrm{CD}^{-11 b^{-}}\left(\mathrm{Lin}^{-}\right)$populations of c-kit ${ }^{-}$and c-kit ${ }^{+}$cells. Sorted cells $\left(2 \times 10^{4}\right)$ were transferred intravenously into sublethally irradiated (4.5 Gy) C57BL/6J (CD45.2+) recipient mice. Negative "nil" control mice were injected with Hanks balanced salt solution only. For analysis of short-term cell development, spleen was collected at 20 or 41 days and stained with antibodies specific for CD45.1, CD11c, CD11b, CD8 $\alpha$, and MHC-II. Before flow cytometry, cells were incubated with PI $(1 \mu \mathrm{g} / \mathrm{mL})$ for gating of live $\left(\mathrm{PI}^{-}\right)$cells. Spleens showing CD45.1+ progeny $(>0.05 \%)$ were examined for donor myeloid cells $\left(\mathrm{CD} 11 \mathrm{~b}^{+} \mathrm{CD} 8^{-}\right), \mathrm{CDCs}\left(\mathrm{CD} 11 \mathrm{c}^{+} \mathrm{MHC}-\mathrm{II}^{+}\right)$, and lymphoid cells $\left(C D 11 b^{-} \mathrm{CD}^{+}\right)$. Numbers in gates indicate percentage positive cells. In a second similar experiment, $\mathrm{Lin}^{-} \mathrm{C}-\mathrm{kit}^{-}$and $\mathrm{Lin}^{-} \mathrm{C}-\mathrm{kit}^{+}$cells were sorted and transferred into lethally irradiated ( $9.5 \mathrm{~Gy}$ ) host mice and analyzed for donor progeny $\left(\mathrm{CD} 45.1^{+}\right)$after 25 weeks. T-/B-cell depleted spleen was analyzed for DC $\left(\mathrm{CD} 11 \mathrm{c}^{+}\right)$and myeloid cell $\left(\mathrm{CD} 11 \mathrm{~b}^{+} \mathrm{CD} 11 \mathrm{c}^{-}\right)$progeny. $\mathrm{T}-/ \mathrm{B}-\mathrm{cell}$ enriched spleen was analyzed for lymphoid $\mathrm{T}\left(\mathrm{CD} 8^{+}\right)$and $\mathrm{B}\left(\mathrm{CD} 19^{+}\right)$cells.

subset of adult spleen, which contains hematopoietic stem cells. Because no CD34 subset was found among adult spleen, c-kit, rather than $\mathrm{CD} 34$, is a defining marker of L-DC progenitors. The possibility that the L-DC progenitor is endogenous to spleen is supported by evidence that blood does not contain precursors, which seed cocultures for L-DC production. ${ }^{24,25}$

Although adult $\mathrm{Lin}^{-} \mathrm{c}-\mathrm{kit}^{+}$spleen progenitors produce specifically L-DCs in cocultures, this restricted development was not replicated in vivo. This indicates a limitation of stroma for supporting only the development of L-DCs from overlaid spleen or BM cells. ${ }^{24}$ Immediate DC precursors have been defined as cells already expressing lineage markers, such as CD11 $\mathrm{c}^{\text {int }}$ pre-cDCs ${ }^{14}$ or $\mathrm{CD} 11 \mathrm{c}^{-} \mathrm{CD} 8 \alpha^{+}$precursors of $\mathrm{CD} 8 \alpha^{+} \mathrm{cDCs}^{33}$ In addition, in blood, precursors for $\mathrm{cDCs}$ and $\mathrm{pDCs}$ have been identified as cells expressing low levels of CD11c. ${ }^{34}$ The $\mathrm{Lin}^{-} \mathrm{c}-\mathrm{kit}^{+}$subset of spleen does not contain immediate DC precursors because they do not give DC development after 10 days after transfer into mice given sublethal irradiation ( $4.5 \mathrm{~Gy}$; data not shown). This type of experimentation has been used successfully by others to demonstrate the presence of pre-cDCs and pre-CD8 ${ }^{+}$cDCs in spleen. ${ }^{14,33}$ The earliest evidence of progeny from adoptively transferred cells was at approximately 20 days in sublethally irradiated mice. Dendritic and myeloid cell development was detected, perhaps arising from a myeloid progenitor because there was no evidence of lymphopoiesis. Evidence for multipotentiality was obtained at 40 days, but only on adoptive transfer of $\mathrm{Lin}^{-} \mathrm{c}-\mathrm{kit}^{+}$cells. More complete multilineage reconstitution was confirmed in lethally irradiated hosts held for more than 25 weeks. These experiments verified the potential of $\mathrm{Lin}^{-} \mathrm{c}-\mathrm{kit}^{+}$cells to give rise to lymphoid, myeloid, and cDC subsets, indicative of multipotentiality. Only small numbers of donor cells and the difficulty of identifying donor-derived progeny limited these experiments.

The splenic L-DC progenitor is distinct from the common dendritic progenitor and macrophage dendritic progenitor described in BM. The absence of Flt3 expression on c-kit ${ }^{+} \mathrm{L}-\mathrm{DC}$ progenitors in spleen is consistent with recent evidence that the common dendritic progenitor, a c-kit ${ }^{+} \mathrm{Flt} 3^{+}$progenitor of $\mathrm{cDCs}$ and pDCs, is not present in spleen. ${ }^{15,29}$ The L-DC progenitor is also distinct from the macrophage dendritic progenitor in $\mathrm{BM}$, a c-kit ${ }^{+} \mathrm{Flt}^{+}{ }^{+}$progenitor of macrophages and DCs. ${ }^{29,35}$ Production of L-DCs in cocultures or LTCs occurs independently of Flt3-L because splenic stromal cell lines that support L-DCs do not produce Flt3-L. ${ }^{36}$ L-DCs appear therefore to develop independently of cDCs and pDCs, which develop both in vitro and in vivo in response to Flt3-L. ${ }^{12,37}$

Culture of neonatal and adult $\mathrm{c}-\mathrm{kit}^{+}$spleen precursors over STX3 stroma resulted in generation of only myeloid CD11 ${ }^{+}$DCs, consistent with earlier studies demonstrating spleen stromadirected in vitro development of $\mathrm{CD}_{11} \mathrm{~b}^{+}$myeloid DCs from BM ${\mathrm{c}-k i t^{+}}$progenitors. ${ }^{38,39}$ However, using defined precursor subsets from spleen, we here distinguish in vitro development of 2 distinct myeloid DC populations: a CD11 $\mathrm{c}^{+} \mathrm{CD} 11 \mathrm{~b}^{\mathrm{lo}} \mathrm{MHC}-\mathrm{II}^{+} \mathrm{CD} 8 \alpha^{-}$ cDCs or monocyte-derived DCs, and a CD $11 \mathrm{c}^{\text {lo }} \mathrm{CD} 11 \mathrm{~b}^{\text {hi }} \mathrm{MHC}-\mathrm{II}^{-}$ L-DC population. Although populations of ${\mathrm{MHC}-\mathrm{II}^{+}}^{+} \mathrm{DCs}$ were evident in productive cultures, their numbers declined over 30 days, and they became the minority population compared with L-DCs (Figure 6). We have now shown production of L-DCs, but not MHC-II ${ }^{+}$DCs, in cocultures maintained for 6 to 12 months (data not shown). All data are consistent with the presence of a committed progenitor for L-DCs present in spleen, which we characterize as a $\mathrm{Lin}^{-} \mathrm{c}-\mathrm{kit}^{+} \mathrm{CD} 34^{-/+} \mathrm{Flt3}^{-}$cell subset with lymphomyeloid differentiative capacity. These results identifying DC progenitors within spleen conflict with the common model for DC hematopoiesis where progenitors reside and differentiate in BM, so releasing committed DC precursors into blood that enter spleen for further differentiation. This finding is, however, consistent with a model for DC hematopoiesis endogenous to spleen and dependent on maintenance of early $\mathrm{Lin}^{-} \mathrm{c}-\mathrm{kit}^{+} \mathrm{Flt} 3^{-}$progenitors that are also clearly distinct from the CD11 $\mathrm{c}^{\text {lo }}$ immediate precursors of $\mathrm{cDCs}$ and pDCs described previously. ${ }^{14}$

Spleen LTCs have been shown to maintain the production of immature, myeloid dendritic-like cells for years. ${ }^{34}$ This property of cell production is consistent with the maintenance of self-renewing progenitors within the stromal microenvironment. In a previous study, progenitors in LTCs were identified among the heterogeneous small cell population previously essential for continued 
production of LTC-DCs. ${ }^{16,19,40}$ Here, similar precursors of L-DCs have been identified as Lin $^{-} \mathrm{c}-\mathrm{kit}^{+}$cells in both neonatal and adult spleen, consistent with the spleen origin of LTCs. The $\mathrm{Lin}^{-} \mathrm{c}-\mathrm{kit}^{\mathrm{hi}}$ spleen subset resembles hematopoietic stem cells in BM as

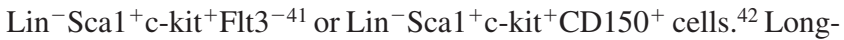
term spleen cultures, or the spleen stromal cocultures described here, therefore represent a potentially important in vitro model system in which to study both the maintenance of hematopoietic progenitors and the microenvironmental signals supporting hematopoiesis of novel DCs.

\section{Acknowledgments}

T. J. O'Neill (Professor of Applied Statistics, ANU) provided statistical support and advice for this project.
This work was supported by ANU institutional funding (H.O.). J.K.H.T. and P.P. were supported by ANU Graduate Scholarships.

\section{Authorship}

Contribution: J.K.H.T. designed, implemented, and analyzed the experiments and prepared the manuscript; P.P. designed, performed, and analyzed the experiments; and H.C.O. supervised the project and contributed to design and analysis of experiments and preparation of the manuscript.

Conflict-of-interest disclosure: The authors declare no competing financial interests.

Correspondence: Helen C. O'Neill, Research School of Biology, Bldg No. 41, Linnaeus Way, Australian National University, Canberra, ACT, Australia, 0200; e-mail: Helen.ONeill@anu.edu.au.

\section{References}

1. Banchereau J, Steinman RM. Dendritic cells and the control of immunity. Nature. 1998;392(6673): 245-252.

2. Liu K, lyoda T, Saternus M, et al. Immune tolerance after delivery of dying cells to dendritic cells in situ. J Exp Med. 2002;196(8):1091-1097.

3. Vermaelen KY, Carro-Muino I, Lambrecht BN, et al. Specific migratory dendritic cells rapidly transport antigen from the airways to the thoracic lymph nodes. J Exp Med. 2001;193(1):51-60.

4. Cella M, Salio M, Sakakibara Y, et al. Maturation, activation, and protection of dendritic cells induced by double-stranded RNA. J Exp Med. 1999;189(5):821-829.

5. Xu Y, Zhan Y, Lew AM, et al. Differential development of murine dendritic cells by GM-CSF versus Flt3 ligand has implications for inflammation and trafficking. J Immunol. 2007;179(11):7577-7584.

6. Vremec D, Pooley J, Hochrein $\mathrm{H}$, et al. CD4 and CD8 expression by dendritic cell subtypes in mouse thymus and spleen. J Immunol. 2000;164(6):29782986.

7. Asselin-Paturel C, Boonstra A, Dalod M, et al. Mouse type I IFN-producing cells are immature APCs with plasmacytoid morphology. Nat Immunol. 2001;2(12):1144-1150.

8. Nakano H, Yanagita M, Gunn MD. CD11c(+)B220 $(+) \mathrm{Gr}-1(+)$ cells in mouse lymph nodes and spleen display characteristics of plasmacytoid dendritic cells. J Exp Med. 2001;194(8):1171-1178.

9. Inaba K, Inaba M, Romani N, et al. Generation of large numbers of dendritic cells from mouse bone marrow cultures supplemented with granulocyte/ macrophage colony-stimulating factor. J Exp Med. 1992;176(6):1693-1702.

10. Sallusto F, Lanzavecchia A. Efficient presentation of soluble antigen by cultured human dendritic cells is maintained by granulocyte/macrophage colony-stimulating factor plus interleukin 4 and downregulated by tumor necrosis factor alpha. $J$ Exp Med. 1994;179(4):1109-1118.

11. Brasel K, De Smedt T, Smith JL, et al. Generation of murine dendritic cells from flt3-ligand-supplemented bone marrow cultures. Blood. 2000; 96(9):3029-3039.

12. Naik SH, Proietto Al, Wilson NS, et al. Cutting edge: generation of splenic CD8+ and CD8- dendritic cell equivalents in Fms-like tyrosine kinase 3 ligand bone marrow cultures. J Immunol. 2005; 174(11):6592-6597.

13. Naik SH, Sathe P, Park HY, et al. Development of plasmacytoid and conventional dendritic cell subtypes from single precursor cells derived in vitro and in vivo. Nat Immunol. 2007;8(11):1217-1226.

14. Naik $\mathrm{SH}$, Metcalf $D$, van Nieuwenhuijze A, et al.
Intrasplenic steady-state dendritic cell precursors that are distinct from monocytes. Nat Immunol. 2006;7(6):663-671.

15. Onai N, Obata-Onai A, Schmid MA, et al. Identification of clonogenic common Flt3+M-CSFR+ plasmacytoid and conventional dendritic cell progenitors in mouse bone marrow. Nat Immunol. 2007;8(11):1207-1216.

16. Wilson HL, Ni K, O'Neill HC. Identification of progenitor cells in long-term spleen stromal cultures that produce immature dendritic cells. Proc Natl Acad Sci U S A. 2000;97(9):4784-4789.

17. O'Neill HC, Wilson HL, Quah B, et al. Dendritic cell development in long-term spleen stromal cultures. Stem Cells. 2004;22(4):475-486.

18. Quah B, Ni K, O'Neill HC. In vitro hematopoiesis produces a distinct class of immature dendritic cells from spleen progenitors with limited T cell stimulation capacity. Int Immunol. 2004;16(4): 567-577.

19. Wilson HL, O'Neill HC. Dynamics of dendritic cell development from precursors maintained in stroma-dependent long-term cultures. Immunol Cell Biol. 2003;81(2):144-151

20. Despars G, Ni K, Bouchard A, et al. Molecular definition of an in vitro niche for dendritic cell development. Exp Hematol. 2004;32(3):1182-1193.

21. Despars G, O'Neill HC. Splenic endothelial cell lines support development of dendritic cells from bone marrow. Stem Cells. 2006;24:1496-1504.

22. Despars G, Periasamy P, Tan J, et al. Gene signature of stromal cells which support dendritic cell development. Stem Cells Dev. 2008;17(5):917-927.

23. Despars G, Tan J, Periasamy P, et al. The role of stroma in hematopoiesis and dendritic cell development. Curr Stem Cell Res Ther. 2007;2(1):23-29.

24. Periasamy P, Tan JKH, Griffiths KL, et al. Splenic stromal niches support hematopoiesis of dendritic-like cells from precursors in bone marrow and spleen. Exp Hematol. 2009;37:10601071.

25. Ni K, O'Neill H. Spleen stromal cells support haemopoiesis and in vitro growth of dendritic cells from bone marrow. Br J Haematol. 1999;105(1): 58-67.

26. Ni K, O'Neill HC. Long-term stromal cultures produce dendritic-like cells. Br J Haematol. 1997; 97(4):710-725

27. Ni K, O'Neill HC. Hemopoiesis in long-term stroma-dependent cultures from lymphoid tissue: production of cells with myeloid/dendritic characteristics. In Vitro Cell Dev Biol Anim. 1998;34(4): 298-307

28. Hogquist KA, Jameson SC, Heath WR, et al.
T cell receptor antagonist peptides induce positive selection. Cell. 1994;76(1):17-27.

29. Liu K, Victora GD, Schwickert TA, et al. In vivo analysis of dendritic cell development and homeostasis. Science. 2009;324:392-397.

30. Lai AY, Lin SM, Kondo M. Heterogeneity of Flt3expressing multipotent progenitors in mouse bone marrow. J Immunol. 2005;175(8):50165023.

31. Wolber FM, Leonard E, Michael S, et al. Roles of spleen and liver in development of the murine hematopoietic system. Exp Hematol. 2002;30(9): 1010-1019.

32. Puza B, O'Neill TJ. Generalised Clopper-Pearson confidence intervals for the binomial proportion. $J$ Statist Comput Simulation. 2006;76:489-508.

33. Bedoui S, Prato S, Mintern L, et al. Characterization of an immediate splenic precursor of CD8+ dendritic cells capable of inducing antiviral $T$ cell responses. J Immunol. 2009;182(7):4200-4207.

34. O'Keeffe M, Hochrein H, Vremec D, et al. Dendritic cell precursor populations of mouse blood: identification of the murine homologues of human blood plasmacytoid pre-DC2 and CD11c(+) DC1 precursors. Blood. 2003;101(4):1453-1459.

35. Fogg DK, Sibon C, Miled C, et al. A clonogenic bone marrow progenitor specific for macrophages and dendritic cells. Science. 2006;311 (5757):83-87.

36. Despars G, Ni K, Bouchard A, et al. Molecular definition of an in vitro niche for dendritic cell development. Exp Hematol. 2004;32(12):11821193.

37. Naik SH, Corcoran LM, Wu L. Development of murine plasmacytoid dendritic cell subsets. Immunol Cell Biol. 2005;83(5):563-570.

38. Svensson M, Maroof A, Ato M, et al. Stromal cells direct local differentiation of regulatory dendritic cells. Immunity. 2004;21(6):805-816.

39. Tang H, Guo Z, Zhang M, et al. Endothelial stroma programs hematopoietic stem cells to differentiate into regulatory dendritic cells through IL-10. Blood. 2006;108(4):1189-1197.

40. Wilson HL, O'Neill HC. Identification of differentially expressed genes representing dendritic cell precursors and their progeny. Blood. 2003; 102(5):1661-1669.

41. Christensen JL, Weissman IL. Flk-2 is a marker in hematopoietic stem cell differentiation: a simple method to isolate long-term stem cells. Proc Natl Acad SciU S A. 2001;98(25):14541-14546.

42. Kiel MJ, Yilmaz OH, Iwashita T, et al. SLAM family receptors distinguish hematopoietic stem and progenitor cells and reveal endothelial niches for stem cells. Cell. 2005;121(7):1109-1121. 